\title{
Determinants of a Foreclosure Discount
}

\author{
September 2017 \\ Herman Donner ${ }^{1}$,
}

\begin{abstract}
:
Using a dataset with individual appraisals of foreclosed apartments sold through auction in Stockholm, Sweden, the issue of selection bias and a potential overestimation of a foreclosure related discount on price is addressed. A mean discount of $7.9 \%$ with a corresponding median value of $9.5 \%$ is shown. A hedonic model is also applied. It is found that about half of the impact on price caused by a forced sale is attributable to the search process on the real estate market. These results contrasts from earlier research having explained a negative impact on price to seller motivational factors. These results provide insight towards the dynamics of a negative impact on price caused by a forced sale, and has the potential to allow stakeholders to model a potential discount in greater detail for individual foreclosed properties, and contribute to management of credit risk.
\end{abstract}

JEL-classifications: D80; D82; R30; R31

${ }^{1}$ Division of Building and Real Estate Economics / Center for Banking and Finance

Department of Real Estate and Construction Management

KTH Royal Institute of Technology, Stockholm, Sweden

Drottning Kristinas Väg 30, 100 44, Stockholm, Sweden

herman.donner@abe.kth.se 


\section{Introduction}

Numerous articles have aimed at estimating the impact that a forced sale has on real estate sale price (Campbell et al., 2011; Carroll et al., 1997; Chinloy et al., 2016; Clauretie and Daneshvary, 2009; Forgey et al., 1994; Hardin and Wolverton, 1996; Harding et al., 2012; Pennington-Cross, 2006; Shilling et al., 1990; Springer, 1996; Zhou et al., 2015), with most estimates indicating discounts in excess of 20\% (Campbell et al., 2011; Forgey et al., 1994; Hardin and Wolverton, 1996; Shilling et al., 1990). A major empirical challenge does however arise due to foreclosure status being likely to proxy for unmeasured property characteristics that negatively influence property value. This issue of selection bias therefore has the potential to cause over-estimation of the impact that a foreclosure has on price when applying hedonic models.

Most studies aiming at estimating the magnitude of the price impact of a foreclosure have given attention to separating the effect of a foreclosure on sale price from that of differences in property characteristics between foreclosed properties and those sold on the general market (Clauretie and Daneshvary, 2009; Springer, 1996). However, aside from property condition, foreclosed properties are likely to sell at lower prices for several reasons that are unrelated to property condition, with the most often given explanation for lower prices being that sellers prefer a quick sale over achieving the highest possible sale price (Campbell et al., 2011; Forgey et al., 1994; Shilling et al., 1990). This is however most likely to be the case when lenders have taken ownership of the property before the sale and when the lender has substantial influence on the sale process. A sale through a foreclosure auction, where creditors have limited influence on the sale, requires an alternative explanation. Adding to this issue is that buyers have many reasons for not wanting to pay full price when buying a foreclosed property, given the greater uncertainty associated with such a transaction. So, although seller motivational factors are often mentioned, few studies offer a deeper analysis of why foreclosed properties achieve lower sale prices. By examination of the determinants of a foreclosure discount through measures of local market conditions, this study adds to the stream of literature having examined sales of foreclosed real estate. 
Before anything, a reliable estimate of the price impact of a forced sale is needed to examine the causes of a foreclosure discount. I resolve this issue using a Swedish dataset in which each foreclosed property has been appraised by a professional that estimates; the most likely price to be acbieved if the property were to be sold through an arms-length transaction on the open market. Such an appraised value is representative of all of characteristics, both tangible and intangibles, that influence property value. A remaining negative price impact of a foreclosure must therefore be attributed to the sale mechanism. This study therefore offers a measure that is more reliable as compared to estimates obtained through hedonic regression models. As the average price is $7.9 \%$ lower than the appraised value, with a corresponding median of $9.5 \%$, the estimated discount is in the lower end of estimates provided by earlier research which often shows discounts off more than $20 \%$ - thus indicating that earlier estimates have been upwardly biased as foreclosure status is endogenously related to characteristics that decrease property value. It is however found that the discount varies considerably amongst observations; it therefore makes little sense to talk about a foreclosure discount as if it applies equally to all property. This provides reason for further examination of the causes for why foreclosed properties achieve lower sale prices.

A foreclosure discount is closely related to fact that real estate values are difficult to evaluate. As real estate is a heterogeneous asset with markets characterized by incomplete information, the search process amongst buyers and sellers is characterized by friction, with examples being that it is costly and time consuming for buyers to find information about available objects, their quality and value, whilst sellers face similar difficulty in setting their reservation price and deciding upon the type and appropriate level of marketing. As there is a trade-off between time and effort in relation to individual outcome, buyers who put in more effort into researching the market are also more likely to buy a property that meets their preferences well. Mayer $(1995 ; 1998)$ relates this to real estate sold through auctions as compared to negotiated sales, finding that auctions lead to lower sale prices as the matching of buyers and sellers becomes less efficient due to the time constraint of an auction sale. Following that line of theory, the price discount of an auction sale varies with market sentiment, as the matching of buyers and sellers will take less time during boom periods when there are many market participants, thus lowering such a discount compared to bust periods when sales are expected to take longer time. 
It is reasonable to expect that forced sales are subject to the same conditions as above described for auctions - as such a sale is forced, and therefore will take place regardless of market conditions, whilst sellers on the general market typically can wait for a price at or above their reservation price. A study of foreclosed real estate that relates to this issue is provided by Campbell et al (2011) whom stated that a forced sale illustrates a true bid price of a property thus varying with bid-ask spreads. As the number of transactions typically decreases during down markets, as seller reservation prices are slow to adjust, a discount on price might be partially attributable variations in liquidity. This call into question the definition of a foreclosure discount, for if low liquidity is a consequence of increasing differences between seller and buyer reservation prices, a forced sale might to some extent just illustrate a market value that sellers on the general market choose not to accept, preferring to wait out in hope of achieving a better price by letting the sale take longer time. In line with this line of theory, I find that a foreclosure has a smaller negative impact on price in liquid markets and in markets experiencing increasing property values. Further support towards a relationship between a foreclosure discount and the process of matching buyers and sellers is provided by the finding that properties with values that exceed the neighborhood average sell at larger discounts which is a likely consequence of a smaller pool of prospective buyers. As structural attributes constitute a larger fraction of property value for such properties, rather than land, this is also consistent with research having found that properties that are more difficult to evaluate are less liquid (Wong et al., 2012).

Besides lower sale prices due to a sale mechanism that is limited in time, other characteristics of the sale process of foreclosed property will negatively influence price. Most prominently is that properties are sold as is without guarantees and that foreclosed properties are likely to be perceived as having a lower quality compared to other properties. As quality is difficult to evaluate, lower prices could be described as a consequence of a market for lemons in which perfectly good properties are priced as if buyers without perfect information expect foreclosed properties to be flawed (Akerlof, 1970). So, if foreclosed properties achieve lower sale prices because of buyer expectations of quality, such a discount will vary depending upon the level of expected quality that cannot be initially observed. As the average property in an expensive neighborhood typically is of a higher quality compared to a property in a cheaper 
neighborhood, buyers are likely to expect a higher quality and thus discount the price less as compared a property in a cheap neighborhood. This is also the pattern that I find, as discounts are smaller in expensive neighborhoods.

In addition to providing a reliable estimated value for each foreclosed property, the data of this study offers the benefit of offering a standardized and transparent sale mechanism through a government agency that handles all final debt enforcement. The clear majority of studies of a foreclosure discount have been based upon U.S. data and so called REO (real estate owned) property that has been repossessed by the lender through foreclosure proceedings. Chinloy et al. (2016) points out that although typically referred as interchangeable terms, a foreclosure sale and REO sale are considerably different sale mechanisms. The former referring to selling foreclosed properties to a third party through some sort regulated sale mechanism, whilst the latter depends upon the routines of the lender in question. In the setting of this study, any potential influence on sale price caused by unobserved seller incentives - such as lenders with a weak financial position prioritizing quick sales for lower prices whilst financially stronger lenders might wait for higher prices - can be ruled out. This offers a unique setting when examining variations in achieved discounts across observations; as such variation should be primarily driven by buyer - rather than seller - motivational factors. Basically, as the seller is always the same, there is no variation in how rushed the sale is.

The remainder of this paper is structured as follows: section 2 provides a literature review, section 3 covers the theoretical framework, section 4 describes the data and institutional setting, and section 5 covers the used method and results. Section 7 concludes. 


\section{Background and Review of Previous Literature}

As other studies provide extensive reviews of the stream of literature that estimates the impact on price caused by a foreclosure ${ }^{1}$, this will be covered briefly in Section 2.1 before turning attention towards studies examining the determinants of a foreclosure discount. This is followed by Section 2.2 that provides a review of studies touching upon the relationship between real estate sale prices and sale mechanisms. More specifically the impact of time and search is reviewed, as forced sales are constrained in terms of time - by definition of being forced - in addition to also adding uncertainty and therefore difficulty for prospective buyers to evaluate property value as compared to unforced sales.

\subsection{Estimates and Determinants of a Foreclosure Discount}

That forced sales achieve lower sale prices is typically referred to as a foreclosure discount, although most studies have examined REO sales. Several early studies find that such sales cause a negative price impact of more than 20\% (Forgey et al., 1994; Hardin and Wolverton, 1996; Shilling et al., 1990). Exceptions are provided by Carroll et al. (1997) that estimate a considerably smaller discount in the range of $4-6 \%$, and Springer (1996) that finds no statistically significant differences in prices at all.

A central issue when determining the price impact of a forced sale is to control for property characteristics and location in order to ensure that foreclosure status is not endogenously related to characteristics that negatively influence property value (Clauretie and Daneshvary, 2009). In addition to property and locational characteristics, seller motivational factors that influence price such as a transaction being a cashsale (Clauretie and Daneshvary, 2009; Forgey et al., 1994), and the time a property has spent on the market has been controlled for (Clauretie and Daneshvary, 2009). Noteworthy is that Clauretie and Daneshvary estimate a considerably smaller discount of $7.5 \%$ after controlling for time on market, which is consistent with studies finding that time constrained sales results in lower prices due to less efficient matching of buyer and property. After control of these factors, a remaining negative impact on price is typically

\footnotetext{
1 see for instance Donner et al. (2016)
} 
attributed to being a foreclosure discount. Most research has attributed lower prices to seller incentives to achieve a quick sale to minimize costs of holding a property (Campbell et al., 2011; Forgey et al., 1994; Hardin and Wolverton, 1996; Shilling et al., 1990; Springer, 1996). This explanation does however not hold in a non REO setting such as in Sweden, were creditors have limited influence on the sale process and do not assume ownership of the property.

Campbell et al. (2011) relates a foreclosure discount to market liquidity and bid-ask spreads. As a forced sale reveals a "true" bid price, the price impact of a forced sale will vary with liquidity. A sale through a foreclosure auction is estimated to cause a discount of $27 \%$, sales due to sudden death of the owner a 5$7 \%$ discount, and bankruptcy a 3\% discount. The authors state that it is likely that foreclosure status is correlated with property characteristics that negatively influence property value, but that forced sales due to sudden deaths should be close to randomly assigned.

In a paper that took a new methodological approach compared to earlier research, Harding et al (2012) concluded that the market for REO properties is efficient after measurement of holding period returns subsequent of a foreclosure. The authors estimate that the price discount caused by a foreclosure provides buyers of REO-properties with a $1.4 \%$ higher annual return compared to buyers of similar properties on the regular market, during a seven-year holding period. This provides an upper-bound of an excess return as such properties might have required excess repairs. That REO-properties sell at lower prices is attributed to diverging property characteristics, and that buyers of such properties place different values on property characteristics compared to buyers on the regular market.

Further insight towards the determinants of a foreclosure discount is provided by the finding by Zhou et al. (2015) that a high concentration of REO sales increases the discount and that recent house price appreciation decreases it. It is also found that properties in bad condition are sold at larger discounts. The dynamics of a foreclosure discount is analyzed further by Chinloy et al. (2016), whom compare sales to third party buyers at foreclosure auctions with REO sales as well as sales on the general market. Although often used interchangeably, the authors note that a REO transaction and a foreclosure sale are 
considerably different sale mechanisms. It is found that properties are sold at lower prices at foreclosure actions as compared to REO transactions, which in turn occur at lower prices as compared to the general market. This relationship is found to be rational both from a seller and buyer perspective and explained by the lender's costs of holding a property as well as by varying levels of uncertainty regarding property condition amongst buyers.

A prior study of Stockholm, Sweden, is provided by Donner et al. (2016) that apply a hedonic model to estimate a foreclosure discount on price for single-family houses and apartments. Discounts of $24.6 \%$ and $20.1 \%$ are estimated, respectively. Forced sales of apartments that are limited in time are sold at a $29.1 \%$ discount.

Lastly, the issue of defining a foreclosure discount has been addressed in a few studies. Campbell et al state that if the process of a forced sale adversely impacts property value, the impact of a forced sale on sale price can be interpreted as a total effect on property value. When examining REO sales, a similar argument is made by Zhou et al., stating that a foreclosure discount should be defined as the discount of a typical REO property off the sale price of its normal counterpart in normal condition. By application of an automated valuation model on transactions spanning 2000 to 2012 across 16 U.S. metropolitan areas an average discount of $14.7 \%$ is estimated.

\subsection{Studies on the Impact of Time and Marketing on Real Estate Sales Prices}

Many markets are characterized by incomplete information and dispersion of prices, so that buyers and sellers who want to determine the most favorable price must make an effort. As noted by Stigler (1961), such search is increasingly worthwhile when the dispersion of prices is greater and when the expenditure on the traded good is large. This type of framework is often applied in labor economics when explaining the process of matching job-seekers and employers. Given that the parties on the job market can only enter a few negotiations simultaneously, a central issue facing the jobseeker (that is selling his or her services) is to determine an optimal strategy when choosing amongst offers from employers (who want to 
buy those services), with random timing and compensation. The cost and expected marginal return of search leads to the optimal level of search. Besides the typical application to labor markets, other markets exhibit characteristics such that a search framework applies when explaining the relationship between selling time and sales price. Notably, real estate is a very heterogeneous asset of which market participants with incomplete information trade, meaning that real estate in many respects are traded on a search market (Goetzmann and Peng, 2006).

An early study of information on real estate markets is provided by Courant (1978). When examining racial prejudice amongst real estate sellers, Courant found that a market equilibrium in which some discriminated buyers overpay is sustainable given search costs. Yinger (1981) applied a search model on the transaction process of real estate, where brokers search for buyers without being certain about the number of buyers that the search process will yield. The author notes that heterogeneous preferences amongst buyers and characteristics of properties make the matching of a particular buyer with a specific property uncertain, and beyond the control of the broker. The matching process is therefore dependent on both listing price and a degree of randomness (Yinger, 1981).

The linkage between liquidity and the process of search is studied by Lippman and McCall (1986) who proposed the expected selling time of an asset, given optimal strategy, as a general definition and measure of liquidity. Subsequent studies that model the relationship between marketing time and price, with the underlying logic that the likelihood of finding a buyer with a high willingness to pay increases with time are provided by Haurin (1988) and Yavas and Yang (1995).

Even as the findings of Lippman and McCall (1986) are general in nature, their measure of liquidity has gained most traction within the field of real estate. A stream of literature has examined the impact of timeon-market (TOM) on real estate sales price (An et al., 2013; Anglin et al., 2003; Cheng et al., 2008; Cheng et al., 2015; Forgey et al., 1996; Genesove and Mayer, 1997; Ong and Koh, 2000; Yavas and Yang, 1995). 
Although results have varied, empirical studies have typically found a positive relationship (An et al., 2013), with the impact of marketing time having a diminishing marginal impact on price (Cheng et al., 2008).

Several studies have examined factors that impact the price-TOM relationship, finding that it varies with market conditions (An et al., 2013; Cheng et al., 2008; Cheng et al., 2015). A number of studies examining the price-TOM relationship estimate that marketing time has a greater positive impact on price on markets with increasing property values (An et al., 2013; Cheng et al., 2015). During periods of declining property values, the benefit of search must offset declining property values for the price-TOM relationship to be positive. An et al. (2013) finds that the price-TOM relationship will vary depending on market conditions, although being a generally positive relationship, except for markets with rapidly declining property values. Even as Cheng et al. (2015) do find support for a positive relationship even in declining markets, so that the benefit of search still mitigates the impact of declining values, their findings are stated to not necessarily contradict those by An et al.

A related stream of literature has examined the relationship between sale mechanism and price, typically by examining differences between negotiated sales and auctions (Allen and Swisher, 2000; Mayer, 1995, 1998; Ong, 2006; Quan, 2002). Consistent with matching theory, Mayer (1995) found that auction sales cause lower prices as such a quick sale results in a poorer match between buyer and house as compared to a longer matching process. The theoretical framework predicts larger such discounts in depressed and thinner markets, as fewer potential buyers leads to a worse matching. Following the logic of matching, auction discounts were modelled to be larger for heterogeneous and larger houses as the cost of mismatching is higher as compared to smaller and homogenous houses - this as the sale mechanism matters less when a larger number of buyers put a similar value of the same property (Mayer, 1995, 1998).

Papers examining the incentives of real estate agents by Rutherford et al. (2005) and Levitt and Syverson (2008), illustrate that sale price is influenced by incentives and time, finding that real estate agents achieve higher prices when selling their own properties as compared to when selling on behalf of a client. The 
latter study is also consistent with a positive relationship between price and TOM as properties owned by real estate agents typically stay on the market slightly longer whilst also selling at higher prices. Another aspect of incentives that impact price is provided by Genesove and Mayer (1997;2001), whom examine how loss aversion amongst sellers will impact selling strategies. The authors find that property owners with high loan-to-value ratios tend to set higher listing prices, wait longer when selling, and achieve higher prices as compared to sellers with lower loan-to-value ratios.

An alternative framework of the relationship between marketing time and price that conflicts with the notion that a longer marketing time increases price is provided by the theory of clearance sales by Lazear (1986), implying that a seller that has failed at selling his product during a period will adjust the price during the subsequent period with the magnitude of adjustment given by the information gained during the prior period. The price will therefore be lowered during each period the product remains unsold. Consequently, the price-TOM relationship will be negative. Taylor (1999) finds results that are consistent with Lazear's theory when treating a longer TOM as a signal of the quality of a property, with a theoretical framework showing a negative relationship between TOM and price.

In sum, previous studies that examine the impact of time on price provides sound support towards that priorities (time versus price) and decisions taken by sellers, and the sale mechanism influences price. Given that foreclosures exhibit the same limitations in marketing time as an auction within a matching framework, a discount on price is to be expected. Variations in such a discount are also likely to vary with market thickness and if prices are increasing or decreasing. 


\section{Theoretical Framework}

The data (described in further detail in section 4) illustrates that the price impact of a foreclosure deviates considerably, as seen in figures $2 \mathrm{a}-\mathrm{b}$ that provide a distribution of deviations between sale price and the appraised value as well as a boxplot for these differences over time. Some objects sell at, or considerably above their appraised value, while other sell at prices that are considerably lower. Estimating a discount as if it applied to all foreclosures in equal magnitude therefore makes little sense. The impact of local market conditions which are likely to influence the magnitude of a foreclosure discount are therefore tested as elaborated below:

Firstly, following a search framework, the impact of liquidity is tested. By definition, a forced sale contrasts from sales on the general market as sellers are unable to wait until achieving a price deemed acceptable. The foreclosure discount can therefore be seen as revealing a true bid price of a property, thus increasing with bid-ask spreads and consequently reflecting time-varying market illiquidity (Campbell et al., 2011). Support towards this notion is found as discounts increase in neighborhoods with few transactions. During periods of low liquidity, a "true" market value of property becomes difficult to estimate, this finding therefore highlights the importance of how a foreclosure discount is defined. Lower prices during times of low liquidity is also supported by the framework proposed by Mayer $(1995 ; 1998)$, as the matching of buyer and property is going to be less successful in finding the buyer with the highest reservation bid price is found compared to when the number of potential buyers is greater. That periods of low liquidity are likely to simultaneously exhibit declining property values, does however add complexity to the analysis.

Secondly, heterogeneity in terms of price within neighborhoods is linked to the foreclosure discount. Larger spreads in price should increase a discount, as this increases buyer uncertainty about the value of a property. Consequently, buyer reservation prices are likely to be lower in such a setting. Price heterogeneity is also closely related to price changes and liquidity, as thin markets are likely to be characterized by large spreads of achieved prices. A property in a heterogeneous neighborhood is likely to have fewer prospective buyers that put a similar value on it, and therefore be sold at a larger discount at a 
foreclosure auction compared to a negotiated sale. An additional parallel can be drawn to the findings of Cheng et al (2008), having found that the positive return of TOM on price increases with the volatility of offer prices. In line with this hypothesis, the negative impact on price caused by a foreclosure auction is found to increase with neighborhood heterogeneity in property prices.

Thirdly, property value in relation to neighborhood price level is examined. Properties that deviate from the typical property in the neighborhood are likely to have a narrower appeal and therefore be sold at larger discounts. Such properties are also likely to be more difficult for buyers to evaluate, therefore lowering reservation prices. More specifically, this effect should be seen for properties that are more expensive than the neighborhood average, as the pool of prospective buyers is likely to be larger for a cheap property in an expensive neighborhood compared to an expensive property in a cheap neighborhood. Put differently, if prospective buyers concentrate their search to certain neighborhoods, one would expect that lower priced properties will be attainable for a larger pool of prospective buyers in each neighborhood. Support towards that atypical properties should sell at larger discounts at a foreclosure auction is provided studies having found that atypical properties typically exhibit greater dispersion in offering prices in addition to taking longer time to sell (Cheng et al., 2008; Glower et al., 1998; Haurin, 1988). Given that the positive impact of marketing time on price increases with such dispersion, a forced sale through auction should cause a greater negative impact on price when having a narrow appeal. This pattern is also found, as properties with values higher than the neighborhood average are sold at larger discounts. An apartment with a low value relative to its neighborhood is also likely to have a higher fraction of its value attributed to location rather than attributes. Wong et al. (2012) found that a higher fraction of land value increases liquidity. Higher land values should also positively correlate with density, which in turn should be associated with higher liquidity due to a higher number of properties. The results are consitent with this finding as well, as more liquid assets should sell at lower discounts. Earlier research also supports that the cost of a mismatching between buyer and property is lower for homogenous properties (Mayer, 1995). A parallel can also be drawn to studies of commercial assets, with Shleifer and Vishny (1992) finding that assets with limited alternative use sell at larger discounts during industry wide recessions. 
Fourthly, neighborhood price changes are examined. As increasing property values is likely to increase expectations of future value increases, up markets should increase buyer reservation prices and consequently decrease the negative price impact of a foreclosure. As bid-ask spreads narrow, the negative impact on price caused by a forced sale should decrease. As liquidity and price changes often follow each other, with higher liquidity and closer bid-ask spreads during up markets as compared to down markets, this is closely related to liquidity. Given that this found, the results are concurrent with earlier research on foreclosure discounts, having found that neighborhood value appreciation decreases the discount on price (Zhou et al., 2015). This does however contradict studies on the price-TOM relationship that have found a greater positive impact of TOM during periods of increasing property values (An et al.,2013), as a greater positive impact of marketing time should correspond to a larger negative impact caused by a forced sale.

Fifthly, the linkage between neighborhood price levels and a foreclosure discount is examined. Previous research have attributed larger discounts of properties in lower value areas to the threat of vandalism of vacant properties in such areas motivating lenders to sell quickly at lower prices (Campbell et al., 2011). In the Swedish setting of this study, no such incentive should be persistent as all sales are subject to the same legal framework that does not allow for such an incentive to influence the sale price. However, the pattern of larger discounts in lower priced areas is consistent with buyers being likely to expect properties in lower priced areas to be of a lower quality, as compared to properties in higher priced areas in which homeowners typically take better care of their properties.

In sum, a negative effect on sale price caused by a forced sale is related to the process of price discovery, and buyers lacking information to correctly assess the value of a foreclosed property. This informational issue will in turn vary depending on neighborhood level liquidity, price change, price dispersion and prices. 


\section{Data and Institutional Setting}

Data of forced sales of cooperative apartments in the county of Stockholm, Sweden, sold during 2006 to 2013 was collected at the physical archive of the Enforcement Authority, which is the government agency that handles all sales of foreclosed property in Sweden. Noteworthy is that the Swedish apartment market is somewhat different in an international comparison, as apartment owners do not own the apartment itself, as all owner-occupied apartments are in cooperative form. What is owned, and consequently sold through a foreclosure sale in this case, is the right to use an apartment that comes with owning a share of a housing cooperative. Because of this setting, structural issues of an apartment property are the responsibility of the housing cooperative and not the individual apartment owner. This should therefore mitigate some of the risk and uncertainty for a buyer that a forced sale typically adds.

Each foreclosed apartment is appraised by an appraiser hired by the Enforcement Authority. What is estimated is the: the most likely price to be achieved if the property were to be sold through an arms-length transaction on the open market. The appraiser is not an employee of the Enforcement Authority, and is hired on a contractual basis. There is sound reason to believe that these appraisals are unbiased, as the appraiser must have an authorization that requires a relevant educational background and a minimum of three years of experience as an appraiser. If the appraisal is unbiased and a foreclosure does not depreciate price, one would expect to see roughly the same number of sales achieving prices below their appraised value as sales selling for prices above appraisal. As the data indicates that a foreclosure does indeed depreciate price, the underlying assumption that the appraisal is unbiased is very important.

Forced sales of apartments take two forms, either being a consequence of unpaid debt which has caused creditors to apply for a foreclosure, or sales due to apartment owners having neglected their duties to the housing cooperative (typically unpaid monthly fees but could also be a consequence of having misbehaved as an apartment owner). In the latter case, it is the housing cooperative that applies to the Enforcement Authority for a foreclosure sale. These two forms of sales each number 344, therefore putting the total number of forced observations to 688. These two types of foreclosures are sold at the same auctions at similar conditions, with the difference that a sale initiated by the housing cooperative is limited to three 
attempted auctions whilst regular foreclosures have no such limitation. Although somewhat different, these two types are treated as equal in the empirical part of this paper. Motivation for this is provided by: (1) that the actual sale process in terms of marketing and auction is almost, if not entirely, identical, and (2) the fact that the percentage difference between sale price and the appraised value exhibits no statistically significant difference between the two types. As foreclosures are a rare event in Sweden, the sample should cover all, or almost all, foreclosure sales during the period.

Noteworthy is that a property in foreclosure is owned by its initial owner up-until a foreclosure sale is finalized, i.e. a foreclosure does not transfer ownership of the property as is the case when a lender takes possession of a property. In this setting, lenders will have less influence on the process of selling a foreclosed apartment; as such sales are regulated by the Swedish Enforcement Code (1981:774) and administered by the Enforcement Authority. It is the auctioneer who decides if a sale is to be done, most notably that the requirement that it is not likely that a considerably bigber price could be acbieved at a subsequent auction is met. When it is deemed that this requirement is not met, a foreclosed apartment can be put up for sale at a subsequent auction later. The interpretation of this requirement is however somewhat unclear, as foreclosed apartments typically are sold at prices below their estimated values, with prices that are more than $20 \%$ lower than the estimated value being common, as illustrated by figure $2 \mathrm{a}$. Unfortunately, the data does not include information regarding which attempted auction a property is sold at.

Before arriving at the final sample, observations with sale prices that deviate from their appraised values with more than $50 \%$ are excluded, as it indicates issues with the appraisal. Apartments in neighborhoods with fewer than 10 transactions during the year in question are also excluded. After such exclusion, 627 forced sales remain, of which 342 are foreclosures and 325 are sold because of a housing cooperative applying for a forced sale. Both types of forced sales are conducted through physical auctions at the Enforcement Authority's Stockholm office. An immediate down payment of $25 \%$ is required, with full payment typically being required within a month. Un-forced sales can often be bought with lower down payments in Sweden, a partial explanation for a discount on price could therefore be that buyers with little equity are unable to pay a $25 \%$ down payment. 
Measures of market sentiment are created through data with sales through real estate agents provided by Valueguard which covers the period of 2006 to 2013. These number 180,466 and have significant market coverage $^{2}$. This data is aggregated to neighborhood level through GIS software, with the neighborhood measure being so called Base Areas which are used by Stockholm County for statistical purposes. The abovementioned 627 forced transactions are in 274 distinct Base Areas for which annual values of the average square meter price, the number of transactions, price dispersion and yearly change in per square meter prices are estimated using the abovementioned transaction data.

Table 1 provides descriptive statistics of the samples of non-forced and forced apartment transactions. Noteworthy is that the apartment characteristics in terms of size, number of rooms and floor do not deviate much. However, the average price of forced sales is considerably lower at about 1.255 million Swedish Crowns ${ }^{3}$ as compared to 2.112 million for non-forced apartments. This difference does by itself not indicate a discount on price, as exemplified by the average appraised value of apartments sold through a forced sale that is 1.349 million. That apartments sold through forced sales have substantially lower appraised values despite similar characteristics illustrates the difficulty of estimating the price impact of a foreclosure through hedonic models. Given similarities in characteristics, the fact that apartments sold through forced sales have lower values must be attributed to location or omitted characteristics, with the former being supported by the circumstance that a considerably higher proportion of forced sales have a balcony - which is consistent with being in neighborhoods further away from the expensive city center in Stockholm were balconies are comparably rarer.

Figures 1a-b illustrate that foreclosed properties are clustered in lower priced areas, with figure 1 a showing average square meter apartment prices in each Base Area during the period of 2006 to 2013. Figure 1b shows the foreclosure rate ${ }^{4}$ for the same areas during the period. The figures show that Stockholm can in large be described as a monocentric city, with prices decreasing with distance to the city center, and that forced sales typically occur in suburban, lower priced neighborhoods outside of the city center.

\footnotetext{
2 No exact number of the market coverage is available, but it is likely in the $80-90 \%$ range. Valueguard provides real estate price indices that are widely distributed in Sweden that are based on this database. 3 As of October 13 2016, one Swedish Crown corresponds to approximately 0.11 US Dollars

${ }^{4}$ In this case the foreclosure rate is defined as the number of foreclosures as a percentage of all sales.
} 
Figures $2 \mathrm{a}-\mathrm{b}$ provides an illustration of the effect a forced sale has on price. Figure $2 \mathrm{a}$ shows the distribution of the deviation of sale prices from the appraised value. The graph shows that most apartments are sold at a discount, illustrated by the rightward skewness of the distribution. There is also considerable variation in prices, with a great number of apartments being sold above their appraised value. As the data covers the fairly long period of 2006 to 2013 , it is of interest to see if the price impact has varied over time. Figure $2 \mathrm{~b}$ therefore provides boxplot graphs by year as well as for the entire period. Some variation can be seen, most notable is that discounts on price increased in 2008 and 2009 when the Stockholm property market was depressed during the financial crisis, discounts then decrease in the subsequent years when the property market rebounded. This therefore seems to support a correlation between market sentiment and the impact that a forced sale has on price.

Amongst the abovementioned 627 apartments that have been sold through a forced sale, the sale price is $7.9 \%$ lower than the appraised value on average. The corresponding median value is higher, at $9.5 \%$, illustrating a skewness of the data. These values are considerably lower than research indicating discounts above $20 \%$, and are like estimates below $10 \%$ as those by Springer (1996) and Clauretie and Daneshvary (2009).

Figures 3a-e provide distributions of the difference between sale price and appraisal by quartiles of apartment value (total), and neighborhood market characteristics. Figure 3a show that apartments with a lower value tend to sell at a greater discount, as seen when comparing the distributions of the first and fourth quartiles of apartment values. Figure $3 \mathrm{~b}$ illustrates the same relationship, not for individual apartment value, but for neighborhood average price. This is done on prices per square meter as this provides a more reliable measure of the general price level of a neighborhood compared to total prices. It is illustrated that discounts tend to be lower for properties in more expensive neighborhoods. Figure $3 \mathrm{c}$ shows the impact of liquidity, showing that discounts are considerably higher in neighborhoods in the lowest quartile of the number of transactions as compared to those in the fourth quartile. Figure $3 \mathrm{~d}$ illustrates the impact on neighborhood price change, showing a negative relationship between neighborhood price change and a foreclosure discount, i.e. that discounts are found to be higher in 
markets with declining values. The correlation between discounts and neighborhood price dispersion is shown in figure $3 \mathrm{e}$, showing that forced sales in neighborhoods that are heterogeneous in terms of price lead to higher discounts.

These abovementioned measures of market sentiment are of course closely related, as higher priced apartments will tend to be in higher priced areas and liquidity tending to be higher when prices are increasing. Therefore, the regression analysis described in the next section will provide a deeper analysis of the relationship between local market conditions and the impact on price caused by a forced sale. 
Table 1 - Apartment Characteristics (Mean Values with Standard Deviations in Parenthesis).

\begin{tabular}{|c|c|c|}
\hline & Non-Forced & Forced \\
\hline No. of Obs. & 180,466 & 627 \\
\hline Sale Price (Swedish Crowns) & $\begin{array}{l}2,118,798 \\
(1350029)\end{array}$ & $\begin{array}{l}1,255,483 \\
(1492976)\end{array}$ \\
\hline $\begin{array}{l}\text { Appraised Value } \quad \text { (Swedish } \\
\text { Crowns) }\end{array}$ & & $\begin{array}{l}1,348,907 \\
(1652347)\end{array}$ \\
\hline Discount (Swedish Crowns) & & $\begin{array}{l}-93,424.24 \\
(357265.6)\end{array}$ \\
\hline Discount (Percent) & & $\begin{array}{l}-.0789708 \\
(.1567924)\end{array}$ \\
\hline Living Area (sqm) & $\begin{array}{l}64.40645 \\
(24.88668)\end{array}$ & $\begin{array}{l}64.7429 \\
(28.38211)\end{array}$ \\
\hline No. of Rooms & $\begin{array}{l}2.395077 \\
(1.041929)\end{array}$ & $\begin{array}{l}2.307018 \\
(1.087725)\end{array}$ \\
\hline Floor Number & $\begin{array}{l}2.146648 \\
(2.430174)\end{array}$ & $\begin{array}{l}2.082137 \\
(2.077769)\end{array}$ \\
\hline Monthly Fee (Swedish Crowns) & $\begin{array}{l}3334.497 \\
(1385.681)\end{array}$ & $\begin{array}{l}3623.724 \\
(1587.715)\end{array}$ \\
\hline Balcony $(1 / 0)$ & $\begin{array}{l}.1219399 \\
(.3272173)\end{array}$ & $\begin{array}{l}.7559809 \\
(.429847)\end{array}$ \\
\hline Elevator $(1 / 0)$ & $\begin{array}{l}.5574291 \\
(.4966923)\end{array}$ & $\begin{array}{l}.5964912 \\
(.4909928)\end{array}$ \\
\hline Age (Years) & $\begin{array}{l}50.33991 \\
(32.83748)\end{array}$ & $\begin{array}{l}44.97767 \\
(27.23703)\end{array}$ \\
\hline
\end{tabular}



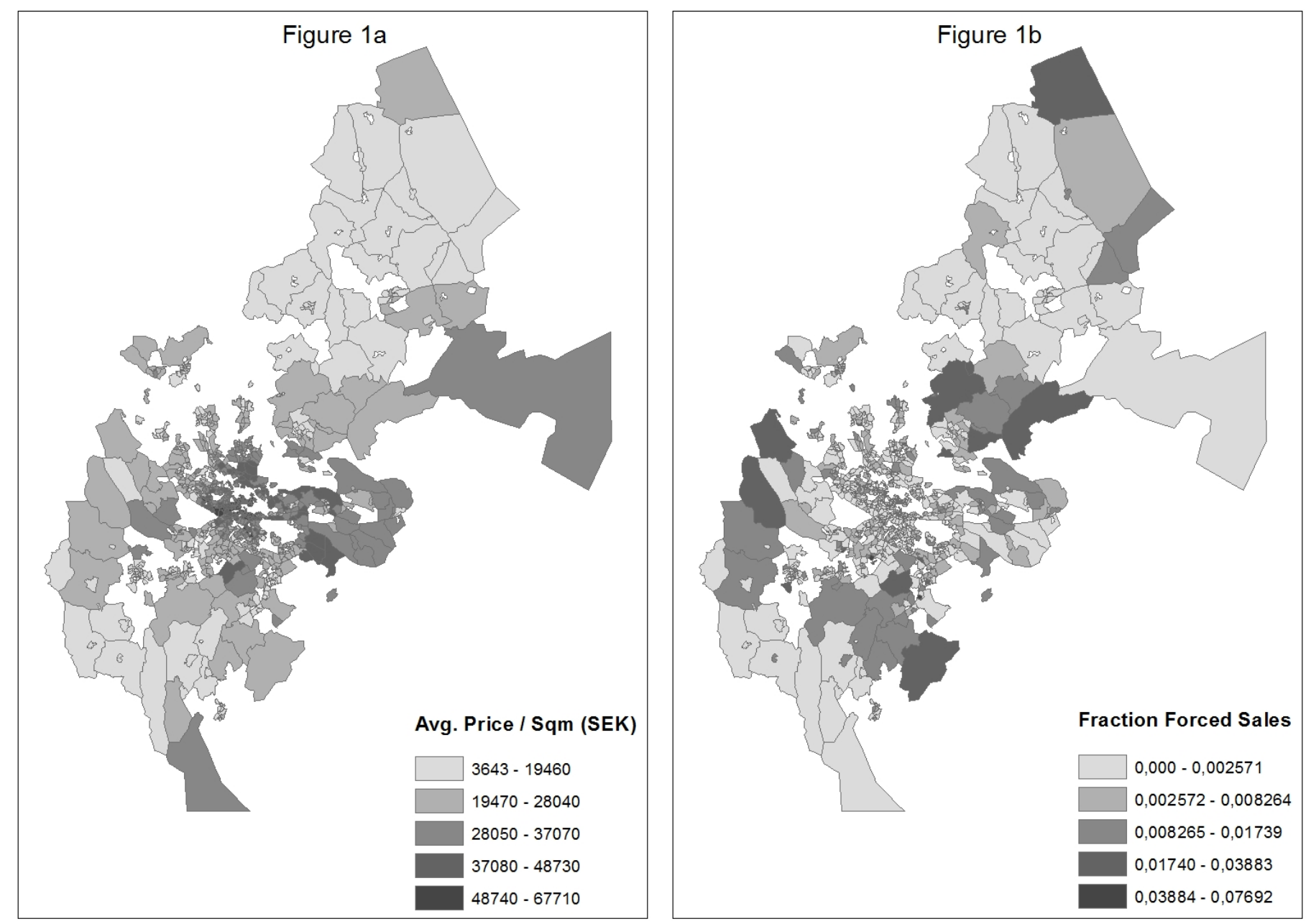

Figure 1a - Stockholm County by neighborhood average square meter price (Swedish Crowns) during 2006 to 2013. Neighborhoods with fewer than 50 transactions during the period are excluded.

Figure $1 \mathrm{~b}$ - Stockholm County by percentage of neighborhood forced sales in relation to total transactions during 2006 to 2013 . Neighborhoods with fewer than 50 transactions during the period are excluded 

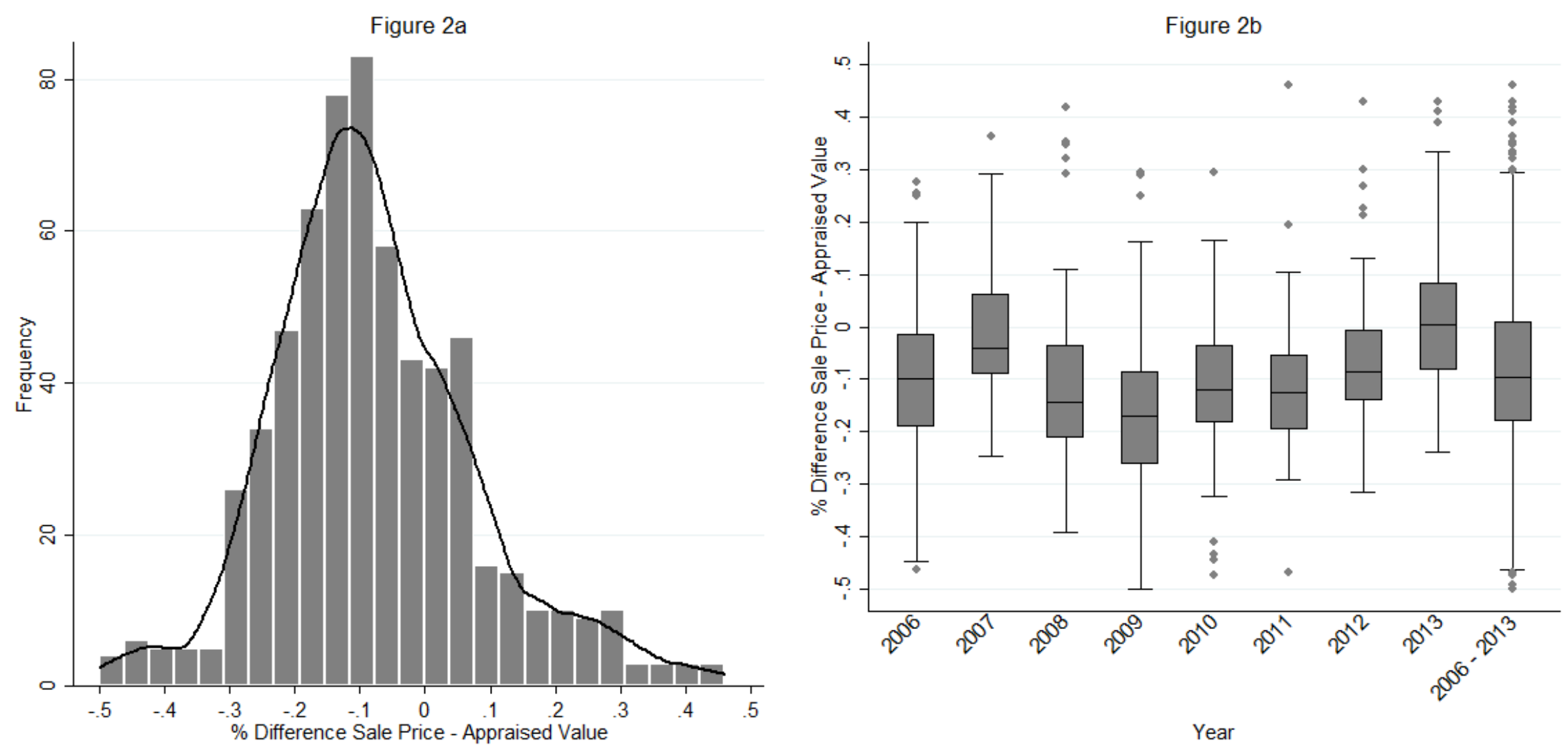

Figure 2a - Distribution of Percentage Differences Between Sale Price and Appraised Value.

Figure $2 \mathrm{~b}$ - Boxplot of Percentage Differences Between Sale Price and Appraised Value by Year 


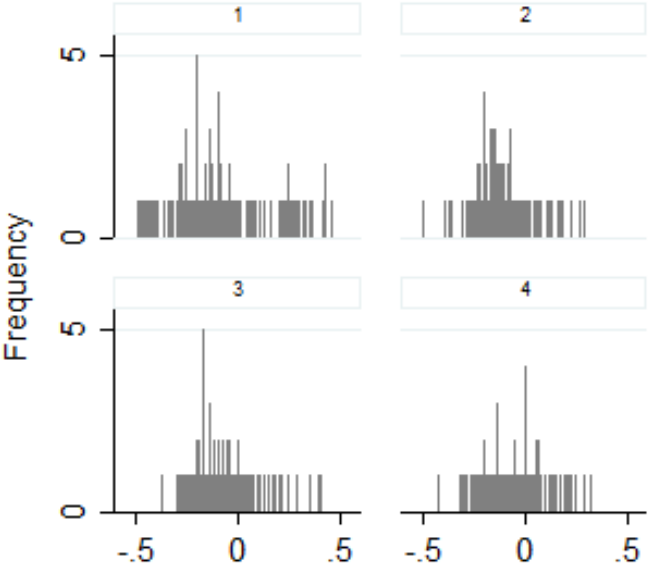

$\%$ Difference Sale Price - Appraised Value Graphs by 4 Quantiles of Appraised Value

Figure 3d

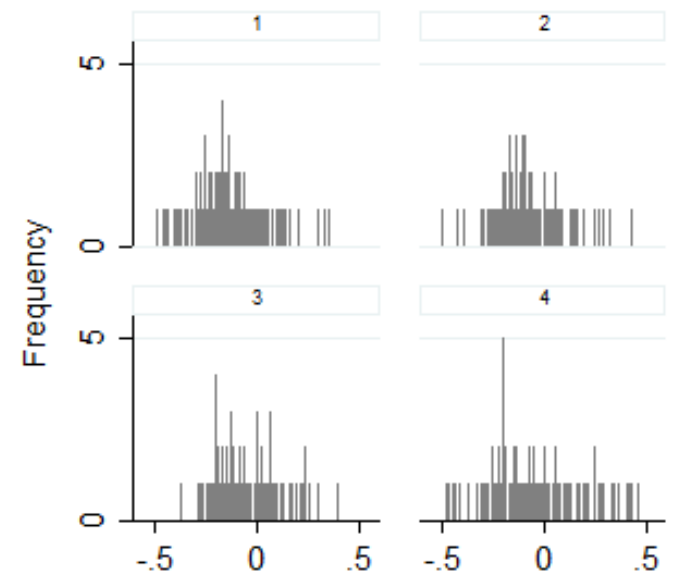

$\%$ Difference Sale Price - Appraised Value Graphs by 4 Quantiles of Change in Area Sqm Price

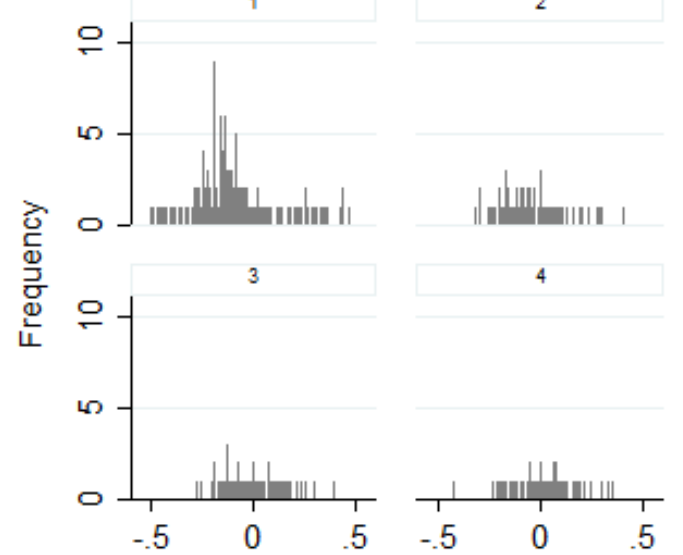

$\%$ Difference Sale Price - Appraised Value Graphs by 4 Quantiles of Avg. Area Sqm Price

Figure $3 \mathrm{e}$

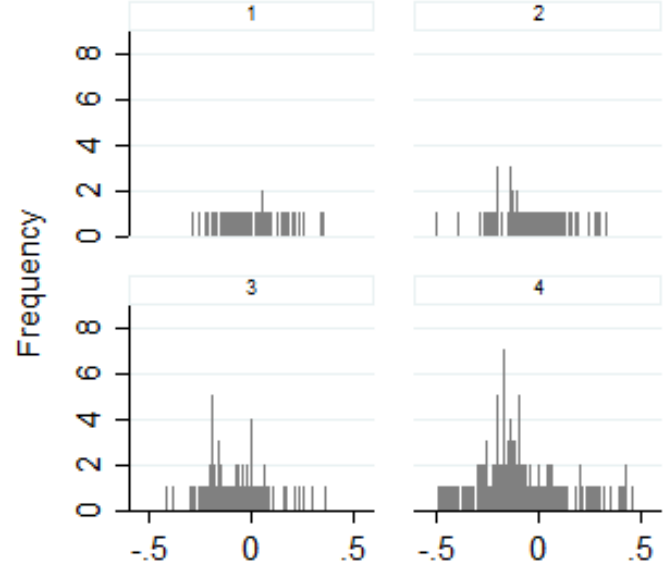

$\%$ Difference Sale Price - Appraised Value Graphs by 4 Quantiles of Area Price Dispersion
Figure $3 c$

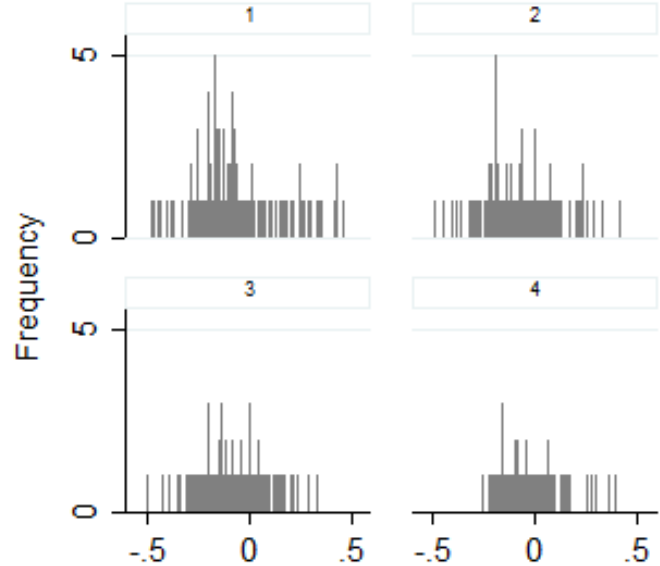

$\%$ Difference Sale Price - Appraised Value Graphs by 4 Quantiles of No. of Area Transactions 
5. Methodology and Results

\subsection{Estimation using Appraisal Values}

To test how market sentiment impacts the difference between the achieved discount (or premium) of a foreclosed apartment, a regression model that is defined as (1) is applied;

Pct Deviation from Value $_{i}=X_{i} \beta+\varepsilon$

Meaning that the percentage deviation between the appraised value and sale price for observation $i$ is regressed on $X$, which is a matrix of local neighborhood market conditions as well a variable indicating the percentage deviation of the appraised value from the average neighborhood price. Because of the nature of the dependent variable, a positive (negative) coefficient of an independent variable indicates a higher (lower) sale price relative to an apartment's appraised value i.e. a smaller (higher) discount on price.

In models 1 and 2, the deviation between sale price and appraised value is a function of the following neighborhood market characteristics; the average price per square meter, the number of transactions during the year of in question, the price dispersion ${ }^{5}$ and the percentage change in average square meter prices. To test if variation in the dependent variable over time confounds the results, the model 2 includes time dummies. This does not change the overall results, except for the number of transactions being statistically significant at the 10\% level in model 2 while not being so in model 1.

The expected effect is that higher priced neighborhoods should be associated with lower discounts, i.e. having a positive coefficient, as this is supported by previous research such as Campbell et al. (2011) and Zhou et al. (2015). Earlier studies have related this combination to seller costs of protection. It could however be an expected pattern from a buyer perspective as well, as a lower percentage discount still corresponds to a large discount in cash.

\footnotetext{
5 This is estimated as the standard deviation of the average square meter price divided by the average square meter price for the year of transaction.
} 
The number of transactions provides a measure of liquidity, and should lead to lower discounts given that higher liquidity leads to a better match between buyer and property for a given period of marketing.

The same logic can be applied to the price dispersion of a neighborhood, as properties in heterogeneous neighborhoods will have fewer prospective buyers compared to neighborhoods with many similar properties. Also, motivating larger discounts is that a large span of prices will increase uncertainty regarding property value. Price dispersion therefore offers a measure of the complexity for buyers to arrive at their reservation bid price.

Properties in markets experiencing increasing property values should be sold at lower discounts, consistent with the patterns regarding foreclosure discounts (Zhou et al., 2015) and auction sales (Mayer, 1995, 1998). As bid-ask spreads are likely to be smaller when property prices are increasing, forced sales that reveal true bid-prices will sell at lower discounts during such periods. Price change can also be a measure of expectations, as expectations of increasing prices are likely to increase reservation bid prices.

All the above-mentioned variables show their expected signs. In addition to measures of local market characteristics, the deviation between the appraised value of the apartment and the area average property price is included in models 3 and 4. As this allows for separation of the neighborhood price level and value of the individual property, this shows the effect of property price in relation to the neighborhood average price. This variable is found to be negative and statistically significant, meaning that apartments with higher values relative to their neighborhood sell at larger discounts. This is the expected result and can be explained by the fact that such properties are likely to have a narrower appeal and a smaller pool of prospective buyers. Such properties are therefore less liquid compared to properties with a value closer to the neighborhood average price level. An additional explanation for this pattern is that if location within a neighborhood is the primary source of value for an apartment, the risk of potential flaws regarding the condition of the apartment becomes a smaller percentage of the sale price, which in turn causes a smaller percentage impact on price caused by the fact that buyers discount risks associated with buying foreclosed property as is without guarantees. A higher fraction of value being attributed to apartment characteristics, in contrast to location, should increase discounts. 
Besides these measures, models that included binary variables that indicate the quarter of sale are also applied to control for variation of general economic conditions that might endogenously influence a discount or premium of forced sales over time and therefore confound the results. Reassuringly, all variables show their expected sign regardless of including time fixed-effects.

The first model explains $14.7 \%$ of the variation of the impact on price caused by a forced sale, with all variables being statistically significant except for liquidity (measured as the number of transactions the year in question). When adding time fixed-effects in model 2 , the explanatory power increases to $24.8 \%$ with liquidity becoming significant at a $10 \%$ level.

Models 3 and 4 include the deviation between the appraised value and average neighborhood price as an explanatory variable. The explanatory power is $19.2 \%$ when excluding time fixed-effects and $28.9 \%$ when such effects are included. As expected, it is found that properties that are expensive relative to their neighborhood are sold at larger discounts. These models provide similar results to the first model, with all variables statistically significant at a $1 \%$ level except for liquidity.

The results show that heterogeneity in prices and expectations are strong drivers of a negative impact on price caused by a forced sale. The results of all models support that a lack of information amongst buyers and expectations about property condition and future value development influences reservation bid prices, and consequently a foreclosure discount. 
Table 2 - Regression Results. Dependent variable is the deviation of price from appraised value.

\begin{tabular}{|c|c|c|c|c|}
\hline & Model 1 & "Model 2 & Model 3 & Modell 4 \\
\hline Area Sqm Price & $\begin{array}{l}2.40 \mathrm{e}-06 \\
(6.00)\end{array}$ & $\begin{array}{l}1.87 \mathrm{e}-06 \\
(4.57)\end{array}$ & $\begin{array}{l}2.76 \mathrm{e}-06 \\
(7.29)\end{array}$ & $\begin{array}{l}2.28 \mathrm{e}-06 \\
(5.97)\end{array}$ \\
\hline Area Transactions & $\begin{array}{l}.0001585 \\
(1.52)\end{array}$ & $\begin{array}{l}.0001939 \\
(1.91)\end{array}$ & $\begin{array}{l}.000108 \\
(1.07)\end{array}$ & $\begin{array}{l}.0001432 \\
(1.44)\end{array}$ \\
\hline Area Price Dispersion & $\begin{array}{l}-.2130965 \\
(-2.32)\end{array}$ & $\begin{array}{l}-.2118841 \\
(-2.58)\end{array}$ & $\begin{array}{l}-.2380177 \\
(-2.59)\end{array}$ & $\begin{array}{l}-.2343828 \\
(-2.86)\end{array}$ \\
\hline$\triangle$ Area Sqm Price & $\begin{array}{l}.2889051 \\
(3.91)\end{array}$ & $\begin{array}{l}.1612363 \\
(1.93)\end{array}$ & $\begin{array}{l}.2768501 \\
(3.85)\end{array}$ & $\begin{array}{l}.1673158 \\
(2.00)\end{array}$ \\
\hline $\begin{array}{l}\% \text { Appraisal Deviation from } \\
\text { Area Price }\end{array}$ & & & $\begin{array}{l}-.0886953 \\
(-5.98)\end{array}$ & $\begin{array}{l}-.0861192 \\
(-5.98)\end{array}$ \\
\hline Time Fixed Effects & No & yes & no & yes \\
\hline $\begin{array}{l}\text { Adj } R^{2} \\
\text { No. Obs. }\end{array}$ & $\begin{array}{l}.141 \\
627\end{array}$ & $\begin{array}{l}.248 \\
627\end{array}$ & $\begin{array}{l}.185 \\
627\end{array}$ & $\begin{array}{l}.289 \\
627\end{array}$ \\
\hline
\end{tabular}

Heteroscedasticity robust standard errors are estimated. T-values are shown in parenthesis below the coefficient estimates. Time fixed effects are binary variables indicating the quarter of the sale which are suppressed from the output to save space. 


\subsection{Hedonic Estimation of the Determinants of a Foreclosure Discount}

After having examined the determinants of a foreclosure discount estimated through appraisal data, a comparison with a traditional approach of applying a hedonic model as defined by Rosen (1974) provides several insights. Firstly, the models offer an understanding towards the determinants of price and a foreclosure discount. Secondly, if appraisals provide the most accurate estimated value, a comparison with the hedonic estimate allows for identification of a potential overestimation due to the endogenous nature of foreclosure status. The model is defined as (2):

Sales $_{\text {price }}=e^{X_{i} \beta+\text { Foreclosure }_{i} \gamma+\varepsilon}$

Meaning that the natural logarithm of sales price $i$ is regressed on $X$, a matrix of apartment characteristics and location ${ }^{6}$. Following most research on housing prices, the depend variable is transformed to natural logarithm. An additional binary variable that indicates if an apartment was sold through a foreclosure auction is also included. This model is applied on the abovementioned transaction data in the county of Stockholm during the period of 2006 to 2013 . The output of this model is shown in table 3.

Model 5 includes property characteristics, time and location fixed effects and a binary variable indicating a foreclosure. The explanatory power is very high with an adjusted $\mathrm{R}^{2}$ of .90 , and all independent variables showing their expected signs. Worth mention is that those with insight in to Stockholm property market know that the most expensive apartments are either newly constructed or old, typically being from the turn of the last century. A second-degree polynomial therefore provides the best way to model the effect of age on price.

A foreclosure is found to have a significant and negative impact on price of $23.9 \%$, when interpreted as suggested by Halvorsen and Palmqvist (1980)7 ${ }^{7}$. Although consistent with earlier studies (such as Campbell et al. 2011; Forgey et al. 1994 and Shilling et al. 1990), the estimate is considerably higher than the

\footnotetext{
6 As a measure of location, base areas are used. There are 645 distinct such base areas in the dataset.

7 This implies that all binary variables that shift from 0 to 1 have an impact on price given by $g=100[E x p$ $(\beta i)-1]$, with $g$ being the percentage change.
} 
estimates produced by comparing sales prices with appraised values, which indicates a mean discount of $7.9 \%$ with a corresponding median of $9.5 \%$. It is notable that the difference in estimates is so very large, with the implicit impact on price produced by the hedonic model approximately 2.5 times the median difference between sales price and appraisal. Most earlier research attribute this type of overestimation to foreclosure status being endogenously related to property characteristics that negatively influence price, such as being in a worse condition or having a lower interior standard. If a foreclosure depreciates price to different degrees depending on market conditions as illustrated in the above section, omission of such measures might be an additional cause for overestimation.

To see if the estimated impact of a foreclosure changes when measures of local market conditions is controlled for, model 6 is estimated, in which such measures of local market conditions are included. Besides variables included in model 5 , a measure of neighborhood price per square meter, the number of transactions, price dispersion and change in price are included.

Noteworthy is that the inclusion of locational measures in addition to local market conditions does not cause perfect collinearity as the latter variables vary over time. As controls for location $\left(B a s e A^{2} a^{8}\right)$ are necessary when estimating sales price, the model specification is motivated given that interpretation of the locational variables is not within the aim of this study.

The explanatory variables show their expected signs in model 6, although the negative impact of the neighborhood number of transactions which proxies for liquidity is found to negatively influence price, which is a likely consequence of greater supply depreciating price. Although significant, inclusion of these variables does not change the estimate of the price impact caused by a foreclosure.

\footnotetext{
${ }^{8}$ As previously mentioned, there are 645 base areas. As a robustness check, the hedonic models were also applied using parish as locational measure, these are larger and fewer, with the number of parishes being 70. Although producing a larger negative estimate of the price impact of a foreclosure, the results are otherwise consistent in the sense that all variables relating to local market conditions show the same signs and the estimated impact of a foreclosure decreases when adding interaction variables (from -.342 to $.233)$.
} 
To further examine the relationship between a foreclosure discount and local market characteristics model 7 is applied in which interaction variables that indicate local market conditions and foreclosure status are included. The results of this model show that liquidity positively impacts price when an apartment is a foreclosure as indicated by the positive interaction variable that is significant at the $1 \%$ level. This is consistent with the theoretical framework and search theory. Similarly, the price dispersion within an area is found to negatively influence price of foreclosed apartments, consistent with the line of theory that this decreases the potential number of buyers which in turn lower price when a sale is limited in time. These two interaction variables are the only ones that are statistically significant, but they are also those that are most closely related to the search process on the real estate market.

Although showing their expected signs, interaction variables for neighborhood price and changes in neighborhood price are not statistically significant. This is a likely consequence of these variables being included in their non-interacted form in the model, in addition to locational fixed effects.

The overall results of model 7 illustrate that it makes little sense to discuss a foreclosure discount as if it impacts all properties equally and that the mechanisms that cause a discount needs further examination. The results are consistent with those in the preceding section in which the estimated discount is regressed on local market measures, which adds robustness.

Also notable is that inclusion of the interaction variables decreases the estimated impact that a foreclosure has on price significantly, from $23.9 \%$ in model 5 , to $-11.3 \%$ in model 7 . The difference between these two estimates implies that about half of the negative price impact caused by a foreclosure sale (the difference between $-23.9 \%$ and $-11.3 \%$ ) is attributed to the interaction between a foreclosure and local market measures. This is an important finding of this study, as it contradicts previous research that attributes a discount to seller motivational factors, in addition to also showing that a large part of the negative impact on price caused by a foreclosure is driven by the search process on the real estate market. 
Table 3 - Regression Results. Dependent variable is the natural logarithm of sales price9.

\begin{tabular}{|c|c|c|c|}
\hline & Model 5 & Model 6 & Model 7 \\
\hline Foreclosure & $\begin{array}{l}-.2734847 \\
(-21.96)\end{array}$ & $\begin{array}{l}-.2712857 \\
(-22.45)\end{array}$ & $\begin{array}{l}-.1199591 \\
(-2.18)\end{array}$ \\
\hline Living Area (sqm) & $\begin{array}{l}.0137732 \\
(144.17)\end{array}$ & $\begin{array}{l}.0137414 \\
(144.64)\end{array}$ & $\begin{array}{l}.0137358 \\
(144.54)\end{array}$ \\
\hline No. of Rooms & $\begin{array}{l}.0509371 \\
(34.72)\end{array}$ & $\begin{array}{l}.0500417 \\
(34.43)\end{array}$ & $\begin{array}{l}.050092 \\
(34.45)\end{array}$ \\
\hline Monthly Fee & $\begin{array}{l}-.000088 \\
(-69.98)\end{array}$ & $\begin{array}{l}-.0000856 \\
(-68.48)\end{array}$ & $\begin{array}{l}-.0000855 \\
(-68.48)\end{array}$ \\
\hline Age & $\begin{array}{l}-.0014895 \\
(-16.08)\end{array}$ & $\begin{array}{l}-.001459 \\
(-15.91)\end{array}$ & $\begin{array}{l}-.0014586 \\
(-15.91)\end{array}$ \\
\hline $\mathrm{Age}^{2}$ & $\begin{array}{l}6.15 \mathrm{e}-06 \\
(8.74)\end{array}$ & $\begin{array}{l}6.10 \mathrm{e}-06 \\
(8.79)\end{array}$ & $\begin{array}{l}6.10 \mathrm{e}-06 \\
(8.80)\end{array}$ \\
\hline Balcony $(1 / 0)$ & $\begin{array}{l}.0059878 \\
(4.50)\end{array}$ & $\begin{array}{l}.0056744 \\
(4.31)\end{array}$ & $\begin{array}{l}.0059659 \\
(4.53)\end{array}$ \\
\hline Elevator $(1 / 0)$ & $\begin{array}{l}.0089647 \\
(7.07)\end{array}$ & $\begin{array}{l}.0085953 \\
(6.85)\end{array}$ & $\begin{array}{l}.0087072 \\
(6.95)\end{array}$ \\
\hline Area Sqm Price & & $\begin{array}{l}1.15 \mathrm{e}-06 \\
(4.36)\end{array}$ & $\begin{array}{l}1.15 \mathrm{e}-06 \\
(4.38)\end{array}$ \\
\hline Area Transactions & & $\begin{array}{l}-.0002844 \\
(-13.07)\end{array}$ & $\begin{array}{l}-.0002855 \\
(-13.12)\end{array}$ \\
\hline Area Price Dispersion & & $\begin{array}{l}-.6373342 \\
(-29.73)\end{array}$ & $\begin{array}{l}-.6303007 \\
(.0213729)\end{array}$ \\
\hline$\Delta$ Area Sqm Price & & $\begin{array}{l}.2989845 \\
(31.30)\end{array}$ & $\begin{array}{l}.2979687 \\
(831.23)\end{array}$ \\
\hline Foreclosure*Area Sqm Price & & & $\begin{array}{l}4.43 \mathrm{e}-07 \\
(0.52)\end{array}$ \\
\hline Foreclosure*Area Transactions & & & $\begin{array}{l}.0003667 \\
(2.38)\end{array}$ \\
\hline Foreclosure*Area Price Dispersion & & & $\begin{array}{l}-.9237004 \\
(-4.23)\end{array}$ \\
\hline Foreclosure* $\Delta$ Area Sqm Price & & & $\begin{array}{l}.1698964 \\
(1.38)\end{array}$ \\
\hline Time Fixed Effects & yes & yes & yes \\
\hline Location Fixed Effects & yes & yes & yes \\
\hline $\begin{array}{l}\text { Adj R }{ }^{2} \\
\text { No. Obs. }\end{array}$ & $\begin{array}{l}.9038 \\
181,089\end{array}$ & $\begin{array}{l}.9063 \\
180,461\end{array}$ & $\begin{array}{l}.9064 \\
180,461\end{array}$ \\
\hline
\end{tabular}

Heteroscedasticity robust standard errors are estimated. T-values are shown in parenthesis below the coefficient estimates. Binary variables corresponding to each floor number, binary variables indicating the quarter of the sale, and binary variables indicating the base areas are suppressed from the output to save space.

\footnotetext{
${ }^{9}$ There are 628 fewer observations in models 6 and 7 compared to model 5 due to missing values of change in area price due to a lack of transactions the preceding period.
} 


\section{Conclusion}

Through a dataset with individual appraisals that estimate the most likely price to be achieved if the property were to be sold through an arms-length transaction on the open market a measure of the impact on price caused by a forced sale is estimated to $-7.9 \%$ on average, with a corresponding median value of $-9.5 \%$. This approach resolves the issue of selection bias and foreclosure status being endogenously related to characteristics that negatively influence property value. This sample constitutes all, or almost all, foreclosed apartments sold through auction in Stockholm, Sweden during 2006 to 2013.

A foreclosure discount is related to the search process on the real estate market, and more specifically buyer information and expectations rather than seller incentives which has been the predominant explanation for lower prices in previous research. This is tested through measures of local market sentiment that influence the search process amongst buyers, and consequently the matching of property and buyer. A model that explains a discount estimated with appraisals, and a hedonic regression explaining price is applied, producing consistent results. It is found that discounts are higher in lower priced areas, in less liquid markets (significant in the hedonic model) and neighborhoods that are heterogeneous in terms of price. This is explained by a less effective search process and greater difficulty to assess value in thin markets, and settings with a large dispersion of prices. It is also found that apartments with a higher value relative to their neighborhood price level are sold at larger discounts. This is consistent with an expensive property in a cheap neighborhood having a narrower appeal and therefore being less liquid, consequently selling at larger discounts when the matching process is limited in time. These results are consistent search theory and studies having examined the impact of TOM on real estate prices and liquidation values.

When using a hedonic regression explaining price, the results indicate that about half of the effect on price caused by a foreclosure is driven by the interaction between a foreclosure and local market measures such as liquidity and price dispersion. These results provide insight towards the dynamics of a negative impact on price caused by a forced sale, and adds to previous research that have attributed a discount on price to 
seller motivational factors. The results have the potential to allow stakeholders to model a potential discount in greater detail for individual foreclosed properties, and consequently provide an important tool in management of credit risk. 


\section{Bibliography}

Akerlof, G. A. (1970). The market for" lemons": Quality uncertainty and the market mechanism. The Quarterly Journal of Economics, 488-500.

Allen, M., \& Swisher, J. (2000). An Analysis of the Price Formation Process at a HUD Auction. Journal of Real Estate Research, 20(3), 279-298. doi: doi:10.5555/rees.20.3.jqw1617266516655

An, Z., Cheng, P., Lin, Z., \& Liu, Y. (2013). How do market conditions impact price-TOM relationship? Evidence from real estate owned (REO) sales. Journal of Housing Economics, 22(3), 250-263.

Anglin, P. M., Rutherford, R., \& Springer, T. M. (2003). The trade-off between the selling price of residential properties and time-on-the-market: The impact of price setting. The Journal of Real Estate Finance and Economics, 26(1), 95-111.

Campbell, J. Y., Giglio, S., \& Pathak, P. (2011). Forced Sales and House Prices. American Economic Review, 101(5), 2108-2131.

Carroll, T. M., Clauretie, T. M., \& Neill, H. R. (1997). Effect of foreclosure status on residential selling price: comment. Journal of Real Estate Research, 13(1), 95-102.

Cheng, P., Lin, Z., \& Liu, Y. (2008). A Model of Time-on-Market and Real Estate Price Under Sequential Search with Recall. Real Estate Economics, 36(4), 813-843.

Cheng, P., Lin, Z., Liu, Y., \& Seiler, M. J. (2015). The Benefit of Search in Housing Markets. Journal of Real Estate Research, 37(4), 597-621.

Chinloy, P., Hardin III, W., \& Wu, Z. (2016). Foreclosure, REO, and Market Sales in Residential Real Estate. The Journal of Real Estate Finance and Economics, 1-28.

Clauretie, T. M., \& Daneshvary, N. (2009). Estimating the house foreclosure discount corrected for spatial price interdependence and endogeneity of marketing time. Real Estate Economics, 37(1), 43-67.

Courant, P. N. (1978). Racial prejudice in a search model of the urban housing market. Journal of Urban Economics, 5(3), 329-345.

Donner, H., Song, H.-S., \& Wilhelmsson, M. (2016). Forced sales and their impact on real estate prices. Journal of Housing Economics, 34, 60-68. doi: http://dx.doi.org/10.1016/j.jhe.2016.08.002

Forgey, F. A., Rutherford, R. C., \& Springer, T. M. (1996). Search and Liquidity in Single-Family Housing. Real Estate Economics, 24(3), 273-292. 
Forgey, F. A., Rutherford, R. C., \& VanBuskirk, M. L. (1994). Effect of foreclosure status on residential selling price. Journal of Real Estate Research, 9(3), 313-318.

Genesove, D., \& Mayer, C. (2001). Loss aversion and seller behavior: Evidence from the housing market. The Quarterly Journal of Economics, 116(4), 1233-1260.

Genesove, D., \& Mayer, C. J. (1997). Equity and Time to Sale in the Real Estate Market. The American economic review, 255-269.

Goetzmann, William, and Liang Peng. "Estimating house price indexes in the presence of seller reservation prices." The Review of Economics and Statistics88.1 (2006): 100-112.

Glower, M., Haurin, D. R., \& Hendershott, P. H. (1998). Selling time and selling price: The influence of seller motivation. Real Estate Economics, 26(4), 719-740.

Hardin, W. G., \& Wolverton, M. L. (1996). The relationship between foreclosure status and apartment price. Journal of Real Estate Research, 12(1), 101-109.

Harding, J. P., Rosenblatt, E., \& Yao, V. W. (2012). The foreclosure discount: Myth or reality? Journal of Urban Economics, 71(2), 204-218.

Haurin, D. (1988). The duration of marketing time of residential housing. Real Estate Economics, 16(4), 396410.

Lazear, E. P. (1986). Retail Pricing and Clearance Sales. The American economic review, 76(1), 14-32.

Levitt, S. D., \& Syverson, C. (2008). Market distortions when agents are better informed: The value of information in real estate transactions. The Review of Economics and Statistics, 90(4), 599-611.

Lippman, S. A., \& McCall, J. J. (1986). An operational measure of liquidity. The American economic review, $76(1), 43-55$

Mayer, C. J. (1995). A model of negotiated sales applied to real estate auctions. Journal of Urban Economics, $38(1), 1-22$.

Mayer, C. J. (1998). Assessing the performance of real estate auctions. Real Estate Economics, 26(1), 41-66.

Ong, S. (2006). Price discovery in real estate auctions: The story of unsuccessful attempts. Journal of Real Estate Research.

Ong, S. E., \& Koh, Y. C. (2000). Time on-market and price trade-offs in high-rise housing sub-markets. Urban Studies, 37(11), 2057-2071. 
Pennington-Cross, A. (2006). The value of foreclosed property. Journal of Real Estate Research, 28(2), 193214.

Quan, D. C. (2002). Market mechanism choice and real estate disposition: Search versus auction. Available at SSRN 314960.

Rutherford, R. C., Springer, T., \& Yavas, A. (2005). Conflicts between principals and agents: evidence from residential brokerage. Journal of Financial economics, 76(3), 627-665.

Shilling, J. D., Benjamin, J. D., \& Sirmans, C. (1990). Estimating net realizable value for distressed real estate. Journal of Real Estate Research, 5(1), 129-140.

Shleifer, A., \& Vishny, R. W. (1992). Liquidation values and debt capacity: A market equilibrium approach. The Journal of Finance, 47(4), 1343-1366.

Springer, T. M. (1996). Single-family housing transactions: Seller motivations, price, and marketing time. The Journal of Real Estate Finance and Economics, 13(3), 237-254.

Stigler, G. J. (1961). The economics of information. The journal of political economy, 213-225.

Taylor, C. R. (1999). Time-on-the-market as a sign of quality. The Review of Economic Studies, 66(3), 555-578.

Wong, S. K., Yiu, C. Y., \& Chau, K. W. (2012). Liquidity and Information Asymmetry in the Real Estate Market. The Journal of Real Estate Finance and Economics, 45(1), 49-62. doi: 10.1007/s11146-0119326-z

Yavas, A., \& Yang, S. (1995). The strategic role of listing price in marketing real estate: theory and evidence. Real Estate Economics, 23(3), 347-368.

Yinger, J. (1981). A search model of real estate broker behavior. The American economic review, 71(4), 591605.

Zhou, H., Yuan, Y., Lako, C., Sklarz, M., \& McKinney, C. (2015). Foreclosure Discount: Definition and Dynamic Patterns. Real Estate Economics. 